\title{
Effect of Need, Easy, and Trust on the Intensity of Using the Mobile Health Application to Conduct a Laboratoty Examination (Case Study on Pramita Lab Surabaya Patients)
}

\author{
Mochammad Baihaqi ${ }^{1}$, Denpharanto Agung Krisprimandoyo ${ }^{2}$ \\ ${ }^{1}$ Klinik Utama Prospek, ${ }^{2}$ School Of Business and Management, Universitas Ciputra Surabaya \\ mochammadbaihaqi@gmail.com, \\ agungkris@ciputra.ac.id \\ https://doi.org/10.37715/rmbe.v1i2.2417
}

\begin{abstract}
This study aims to analyze the influence of need, convenience and trust on the intensity of using the mobile health application to perform laboratory examinations on Pramita Lab Surabaya patients. This research is important because the intensity of the use of the mobile health application is influenced by the needs, convenience and trust of patients in the mobile health application. The sample in this study were all 108patients using the mobile health application at Pramita Lab Surabaya. The research design used is quantitative research with a descriptive approach with an emphasis on theory testing through measurement of research variables through distributing research questionnaires. The distribution of research questionnaires was carried out using probability sampling techniques. The analysis technique in this study is to use multiple linear regression analysis with the help of SPSS 20.0 software. The results showed that the variables of need, convenience and trust had a positive and significant effect simultaneously on the intensity of using the mobile health application in patients at Pramita Lab Surabaya. The result also show that there is a positive and significant influence on the need, convenience and trust on the intensity of using the mobile health application by patients at Pramita Lab Surabaya.
\end{abstract}

\section{Keywords - Need, Ease, Trust, Intensity of Use, Mobile Health Application, Pramita Lab Surabaya.}

\section{Introduction}

Technological developments are increasing rapidly. Almost every year there is always the latest technology from various industries, one of which is the health industry. There have been many digital-based health services in the form of mobile health applications, especially in health laboratory companies such as the case study raised in this research is Pramita Lab, where since 2018 Pramita Lab has never been included in the Top Brand Index. Therefore, Pramita Lab currently wants to catch up in providing digital-based services and is currently developing information systems so that services are better and more integrated. Digital-based services aim to provide the public with the convenience of ordering or registering, paying, and getting online inspection results. Then when people use health services online, there is a need, convenience, and trust to show the intensity of using mobile health applications by patients. The level of how often individuals carry out activities based on pleasure in these activities is the definition of intensity according to Yuniar \& Nurwidawati (2013). The intensity of using the mobile health laboratory application for patients shows how easy the application is to use. The ease of use, services and features in it are able to provide a continuous sense of comfort for users so that patient loyalty in using the application will increase and will continue to use it. High patient loyalty to health applications also makes the Laboratory easier and more practical in serving patients.

The problem that usually occurs is when patients do not know and understand the use of health technology, so the intensity of use tends to be minimal. In addition, patients also do not know how to use and about the convenience offered by the technology. Jogiyanto (2007), convenience is where individuals form a sense of trust about information technology in addition to being influenced by individual, institutional and social factors. In addition to the convenience of the patient, the level of trust in the new health technology is also important. In a study conducted by Maharani dan Darmastuti (2010), trust is a belief in one party regarding the durability, reliability and integrity of the other party in the belief and relationship which shows that its activities and actions are capable of producing positive results, something good that can be trusted. by all parties. 


\section{Literature Review}

\subsection{Previous Research}

The first research was conducted by Hamid, et al. (2016). This research is a quantitative research with purposive sampling method as a sampling method. The aim is to analyze the relationship between predictor variables (perceived usefulness and ease of use) and criterion variables that indicate the sustainability of egovernment use. The relevance of this research is that there are similarities between the research variables, namely the ease and usability and the intensity of use or the sustainability of use. The second research was conducted by Chiu et al. (2017). The aim of the study was to assess the direct effects of initial trust antecedents, trust mediating effects and moderating effects of demographic variables on the behavioral intentions of non-adopters to use mobile banking. The relevance of this research is that there are similarities between research variables, namely trust and intensity of use or intention to use mobile banking. The third study, was conducted by Khaddafi, et al (2018). The purpose of this study was to determine the effect of perceived ease, behavioral intensity and user satisfaction in using the e-filing system, especially in Lhokseumawe City. The relevance of this study is that there are similarities in the research variables, namely the ease and intensity of use or the sustainability of use.

\subsection{Theoretical basis}

\subsubsection{Understanding Marketing Management}

In the marketing management function there is an analysis activity, namely an analysis carried out to find out the market and its marketing environment, so that it can be how big the opportunity to seize the market and how big the threat that must be faced (Wahyujatmiko \& Yon Hadi, 2018). Marketing management means all activities ranging from analysis, planning, implementation, control to programming that are made to build, shape, maintain profits from the exchange of target markets for long-term organizational goals (Assauri, 2013).

\subsubsection{Understanding Consumer Behavior}

The study of how groups, organizations, and individuals make choices, make purchases, use and place goods, ideas, experiences, services, and so on to satisfy wants and needs is called consumer behavior (Kotler \& Armstrong, 2008).

\subsubsection{Definition of Mobile Application}

Mobile applications are computer programs designed to run on mobile devices such as smartphones or tablets. Using a smartphone can increase the user's social status, increase the frequency of social interactions, and provide opportunities to get to know other people (Özcan \& Koçak, 2003). A clinical study states that smartphones and mobile applications can be used as treatment materials in abuse (Dahne \& Lejuez, 2015). In libraries, smartphones and mobile applications help users search library collections and find book information (Xu et al., 2015). Mobile devices and mobile applications can also provide interactive e-learning platforms and encourage students to interact, thereby increasing the effectiveness of their learning and increasing their motivation to learn from each other (Shaw \& Tan, 2015).

\subsubsection{Definition of Health Laboratory}

Medical and clinical laboratories are laboratories that aim to obtain patient health information with various tests offered on biological specimens. Public or private laboratories receive samples which will later be analyzed by general practitioners, other health clinicians and insurance companies. Another health clinician is referred to as a reference laboratory where vague and common tests are performed.

\subsubsection{Intensity of Use}

The level of how often individuals carry out activities based on pleasure in these activities is the definition of intensity according to Yuniar \& Nurwidawati (2013). A model that is used to measure the success and use of a system, where this model by researchers is quite valid even though it is simple, the model is a model of the Delone and McLean (2003) model. Measurements in use can be measured in several aspects according to Delone and Mclean (2003), namely the frequency of use or the frequency of using a thing, time of use, namely the time in using something or the time of use, usage pattern or pattern of using a thing and dependency or dependence on something.

2.2.6. Needs

Mustaqim (2017) states that need is a tendency and direction of desire in individuals for something to fulfill daily impulses, interest comes from within who is able to influence movement and will on something which is a 
strong impetus to realize ideals and goals. Needs have a relationship with motivation, so talking about needs must discuss motivation theory.

Indicators of need are divided into three types, namely Need for Achievement or the need for achievement is a desire to implement something more efficiently and better. Need for power or the need for power is a desire to control other individuals, influence the behavior of other individuals and have a high sense of responsibility to them. There are two forms of power, namely the need for personal power and the need for social power. The need for personal power means the need that is capable of involving manipulation for personal gratification and in management will not be successful and also exploitative. While social needs means a power which tend to be positive for the use of power leads to positive things in a way responsible social. Last is Need for Affiliation or affiliation requirement is a desire to establish friendly relations and maintain a warm relationship with another individual.

\subsubsection{Convenience}

Convenience is a position where the individual believes that the use of a particular system may not require effort or in the sense that the use of the system or technology can provide convenience that is understood by the user (Davis, 1989). Ease of using something is defined as the extent to which an individual believes and believes that using a technology will free himself from effort (Hartono, 2009). The indicators of convenience according to Davis (1989) are:

1. There is ease in learning it or easy to learn, where in the next use of the product the difficulty of using it no longer exists.

2. There is ease of operation or understanding, where the product is easy to operate by users and technology that is easy and clear in operation can provide ease of use.

3. The system can do what the user wants to do easily or commonly referred to as easy to get the system to do what the user wants to do. Generally, an item that provides easy facilities and according to individual needs in using, is able to easily do what the user wants.

4. There is convenience in the sign that the effort required for interaction is not much or does not require a lot of mental effort. This means that the sacrifices made are not much when the technology is used by users.

5. Flexibility or flexible where there is the ability to work and adapt in different situations very effectively either on a group or individual.

\subsubsection{Trust}

Trust can be interpreted as an individual's desire to be sensitive to the actions taken by other individuals, with the hope that other individuals will take certain actions on people who believe in them without depending on the ability to control and supervise.

\section{Research Methods}

\subsection{Conceptual Framework}

This study uses quantitative analysis methods to seek market research in analyzing the effect of need, convenience, and trust on the intensity of using mobile health applications for laboratory examinations.

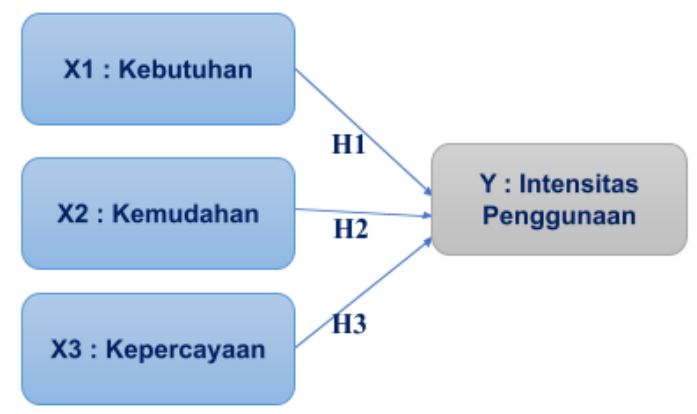

Figure 3.1 Analysis Model

Source: theoretical studies and previous research (2020)

\section{Hypothesis:}

$$
\mathrm{Y}=\mathrm{a}+\mathrm{b} 1 \mathrm{X} 1+\mathrm{b} 2 \mathrm{X} 2+\mathrm{b} 3 \mathrm{X} 3+\mathrm{e}(1
$$

H1-: There is an effect of need on the intensity of using mobile health applications for laboratory examinations 
$\mathrm{H} 2-$ : There is an effect of convenience on the intensity of using mobile health applications for laboratory examinations

H3-: There is an effect of trust on the intensity of using mobile health applications for laboratory examinations

Quantitative methods were used for this research. Quantitative method is a method in the form of statistics or numbers for the sake of presenting research results (Purhantara, 2010, p. 2). According to Sugiyonoo's research (2014), a general area in which there are subjects/objects that have quality and the existence of characteristics that have been determined for analysis purposes and studied to draw conclusions is the definition of the population. The population in this study is emphasized on clinical laboratory patients in 5 branches of Pramita Lab Surabaya so that the total population is 169,501 patients. The best sample has generally been determined by previous researchers, including in the current study where the desired sample is clinical laboratory patients, the determination of the number using the following formula:

$$
\begin{gathered}
n=\frac{N}{\left(1+N e^{2}\right)} \\
n=\frac{169.501}{\left(1+169.501 \times 0.10^{2}\right)}=100
\end{gathered}
$$

Description:

$\mathrm{n} \quad$ : Number of samples

$\mathrm{N} \quad$ : Total population $=169.501$

E : Error (10\%)

Based on the calculation of the formula above, it can be seen that with a population value of 169,501 people, the research sample is 100 people. The sampling technique in this study is probability sampling, which is a sampling technique that provides the same opportunity for each population to be selected as a sample (Sugiyono, 2010). The sample criteria are Pramita Lab Surabaya patients who have done more than one examination. Sampling at various Pramita Lab branches was divided into several people in one branch, including 23 people at HR Muhammad branch, Mulyosari, Jemur Handayani and Parrangkusumo 15 people, Ngagel and Adityawarman 20 people. The research data was collected by means of a questionnaire containing statements with a Likert scale that the respondents would choose to show the suitability of the statement with the ease, trustworthiness and need for the intensity of using mobile health.

\subsection{Data analysis}

\subsubsection{Validity test}

To determine whether an instrument is appropriate or not, the Pearson correlation significance test is carried out. According to Sujarweni (2015), reliability is a test used for significant values $<0.05$. The testing in this study was assisted by SPSS version 20.0 software.

\subsubsection{Reliability Test}

The reliability of the questionnaire is seen from the consistency of a person's answers to questions or statements from time to time. A variable is said to be consistent if it has a Cronbach alpha $>0.6$.

\subsubsection{Regresi Linier Berganda}

In this study, the independent variable is the influence of need, convenience, and trust. Meanwhile, the dependent variable is the intensity of using mobile health applications in conducting laboratory examinations. The general equation of multiple linear regression is as follows:

Description:

$$
Y=a+\beta 1 X 1+\beta 2 X 2+\beta 3 X 3+e
$$

$\mathrm{Y}=$ Intensity of Use

$\mathrm{X} 1=\mathrm{Need}$

$\mathrm{X} 2=$ Ease

$\mathrm{X} 3=$ Trust

$\mathrm{A}=$ Variable/number constant

b1,b2,b3,b4= Regression Coefficient

$\mathrm{e}=$ error 


\subsubsection{Hypothesis testing}

a) $\mathrm{F}$ test

The F significance test is used to determine the relationship between the independent variable and the dependent variable. Do the three independent variables, need (X1), convenience (X2), and trust (X3) really have a simultaneous effect on the dependent variable, namely the intensity of use (Y). If the results of the SPSS analysis show the F test with a significance value of $0>00.05$ then $\mathrm{H} 0$ is accepted and $\mathrm{H} 1$ is rejected, but if the significance value is $0<$ 00.05 then $\mathrm{H} 0$ is rejected and $\mathrm{H} 1$ is accepted

b) $\mathrm{t}$ test

The $\mathrm{t}$ test is used to test whether or not there is a relationship between the independent variables, namely need (X1), convenience (X2), and trust (X3) on the intensity of using mobile health applications (Y). If the significance value of the t-test $<0.05$, it means that $\mathrm{H} 1 \mathrm{~d}$ is accepted, which means that the independent variable has a significant effect on the dependent variable.

Need Variable (X1)

$\mathrm{H} 0: \beta 3=0$ here is no significant effect between need and intensity of using mobile health applications.

$\mathrm{H} 1: \beta 3 \neq 0$ There is a significant effect between the need and the intensity of using mobile health applications.

\section{Convenience Variable (X2)}

$\mathrm{H} 0: \beta 1=0$ There is no significant effect between ease and intensity of using mobile health applications.

$\mathrm{H} 1: \beta 1 \neq 0$ there is a significant effect between the ease with the intensity of using the mobile health application.

\section{Confidence Variable (X3)}

$\mathrm{H} 0: \beta 2=0$ There is no significant effect between trust and the intensity of using mobile health applications. $\mathrm{H} 1: \beta 2 \neq 0$ there is a significant effect between trust and the intensity of using mobile health applications.

\subsubsection{Classic assumption test}

There are various kinds of classical assumption test models that are carried out, namely:

a) Normality test

According to Riduwan (2010), the normality test can be interpreted as a test method carried out in order to provide an indication of whether a regression model has a normal distribution or not. In this case, if the variables are not normally distributed, then a decrease in the statistical test results will occur. However, if the variables are normally distributed, then an increase in statistical test results will occur.

1. If the value significance $>0.05$ then the data has a normal distribution

2. If the value significance $<0.05$ then the data does not have a normal distribution

b) Multicollinearity Test

The presence or absence of multicollinearity can be known by VIF (Variance Interaction Factor). If the value of VIF 10 then there has been multicollinearity in the regression model, whereas if the value of VIF 10 then there is no multicollinearity (Sanusi, 2012).

c) Heteroscedasticity Test

Spearman's rank is to correlate the independent variables with the absolute residuals of the regression results. If the tested variable does not contain heteroscedasticity, then the significance value is greater than 0.05 $(5 \%)$ and vice versa.

\section{d) Linearity Test}

This test is usually used as a prerequisite in correlation analysis or linear regression. A linear relationship occurs when the linearity significance value is $<0.05$ (Noor, 2011).

\subsubsection{Correlation Coefficient $(R)$}

The Pearson correlation coefficient is -1 to +1 . If the value of $R>0$ then the independent and dependent variables are in the same direction. If the value of $\mathrm{R}<0$ then the independent and dependent variables are opposite in direction. If the value of $\mathrm{R} 0$ then the independent and dependent variables are not patterned (Sanusi, 2012). 


\subsubsection{Coefficient of Determination}

According to Kuncoro (2013), a measuring instrument of how far the variation of the dependent variables can be explained by the ability of the model. Test $\mathrm{R}^{2}$ has a value of approximately one criterion if it can be concluded that the independent variables have a close relationship with the dependent variable. However, if the value is close to zero, it can be concluded that the independent variable has a weak relationship with the dependent variable.

\section{Result and Discussion}

This study distributed 120 questionnaires to patients at Pramita Laboratorium Surabaya, then 108 questionnaires were returned to the researcher, so that the researcher used 108 respondents' answers to become research data.

\subsection{Validity test}

Table 4.1. Validity Test Results

\begin{tabular}{|c|c|c|c|c|}
\hline Variable & Indicator & Pearson & Sign & Note: \\
\hline \multirow{3}{*}{ Need (X1) } & Need for achievement & 0,857 & 0.00 & \multirow{15}{*}{ All Items Valid } \\
\hline & Strength requirement & 0,815 & 0.00 & \\
\hline & Relationship needs & 0,831 & 0.00 & \\
\hline \multirow[t]{5}{*}{ Convenience $(\mathrm{X} 2)$} & Easy to learn & 0,801 & 0.00 & \\
\hline & Easy to operate & 0,750 & 0.00 & \\
\hline & Easy to follow user wishes & 0,853 & 0.00 & \\
\hline & It doesn't take much effort to use & 0,867 & 0.00 & \\
\hline & Flexible & 0,809 & 0.00 & \\
\hline \multirow[t]{3}{*}{ Trust (X3) } & Seriousness & 0,840 & 0.00 & \\
\hline & Ability & 0,850 & 0.00 & \\
\hline & Benefit & 0,814 & 0.00 & \\
\hline \multirow[t]{4}{*}{ Intensity of Use (Y) } & Frequency in use & 0,704 & 0.00 & \\
\hline & Usage time & 0,719 & 0.00 & \\
\hline & Usage pattern & 0,645 & 0.00 & \\
\hline & Dependency & 0,882 & 0.00 & \\
\hline
\end{tabular}

Source: Data Processed by Researchers, 2021

Based on the results of the validity test on 30 samples, the variables of need, convenience, trust and intensity of use as a whole are valid because they have a significance value of the variables of need, convenience, trust and intensity of use under 0.05 .

\subsection{Reliability Test}

Table 4.2. Reliability Test Results per Indicator

\begin{tabular}{|c|c|c|c|c|}
\hline & Indicator & $\begin{array}{l}\text { Cronbach's } \\
\text { Alpha }\end{array}$ & $\begin{array}{l}\text { Cronbach's Alpha if } \\
\text { Items Deleted }\end{array}$ & Note: \\
\hline \multirow{3}{*}{ Need (X1) } & KB.1 & 0,776 & 0,712 & \multirow{15}{*}{$\begin{array}{l}\text { Overall } \\
\text { Reliable } \\
\text { Items }\end{array}$} \\
\hline & KB.2 & 0,776 & 0,694 & \\
\hline & KB.3 & 0,776 & 0,690 & \\
\hline \multirow[t]{5}{*}{ Convenience (X2) } & KM.1 & 0,873 & 0,848 & \\
\hline & KM.2 & 0,873 & 0,863 & \\
\hline & KM.3 & 0,873 & 0,835 & \\
\hline & KM.4 & 0,873 & 0,826 & \\
\hline & KM.5 & 0,873 & 0,856 & \\
\hline \multirow[t]{3}{*}{ Trust (X3) } & KP.1 & 0,781 & 0,725 & \\
\hline & KP.2 & 0,781 & 0,668 & \\
\hline & KP.3 & 0,781 & 0,718 & \\
\hline \multirow[t]{4}{*}{ Intensity of Use (Y) } & IP.1 & 0,723 & 0,692 & \\
\hline & IP. 2 & 0,723 & 0,670 & \\
\hline & IP. 3 & 0,723 & 0,698 & \\
\hline & IP.4 & 0,723 & 0,543 & \\
\hline
\end{tabular}

Source: Primary Data Processed, 2021

The results of the reliability test show that the X1 (Needs) indicator has a Cronbach's Alpha coefficient value of $0.776>0.6$ and Cronbach's Alpha if Item Deleted is not more than 0.776. Therefore, the statements in the 
questionnaire can be said to be reliable or acceptable. The results of the reliability test show that the X2 (Ease) indicator has a Cronbach's Alpha coefficient value of $0.873>0.6$ and Cronbach's Alpha if Item Deleted is not more than 0.873 . Therefore, the statements in the questionnaire can be said to be reliable or acceptable. The results of the reliability test show that the X3 (Trust) indicator has a Cronbach's Alpha coefficient value of $0.781>0.6$ and Cronbach's Alpha if Item Deleted is not more than 0.781. Therefore, the statements in the questionnaire can be said to be reliable or acceptable. The results of the reliability test show that the $\mathrm{Y}$ indicator has a Cronbach's Alpha coefficient value of 0.723>0.6 and the value of Cronbach's Alpha if Item Deleted is not more than 0.723 . Therefore, the statements in the questionnaire can be said to be reliable or acceptable.

\subsection{Multiple Linear Regression Analysis}

Table 4.3. Table of Regression Equations

\begin{tabular}{|c|c|c|c|c|c|c|}
\hline & \multirow[b]{2}{*}{ Model } & \multicolumn{2}{|c|}{$\begin{array}{l}\text { Unstandardized } \\
\text { Coefficients }\end{array}$} & \multirow{2}{*}{\begin{tabular}{|c} 
Standardized \\
Coefficients
\end{tabular}} & \multirow[b]{2}{*}{$\mathrm{t}$} & \multirow[b]{2}{*}{ Sig. } \\
\hline & & B & Std. Error & & & \\
\hline & (Constant) & -.584 & 1.040 & & -.561 & .576 \\
\hline & Needs & .411 & .081 & .328 & 5.075 & .000 \\
\hline & Convenience & .336 & .084 & .386 & 3.982 & .000 \\
\hline & Trust & .379 & .130 & .259 & 2,906 & .004 \\
\hline
\end{tabular}

Source: Primary Data Processed, 2021

Based on the results of multiple linear regression analysis in table 5.7, the following regression equation is obtained:

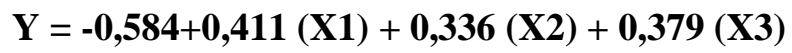

Based on the various parameters in the regression regarding the factors that affect the Intensity of Use, it can be interpreted as follows:.

1. The value of the multiple linear regression coefficient is -0.584 , so it can be interpreted that if the need (X1), convenience (X2) and trust (X3) do not increase or 0 then the value of the intensity of use (Y) is -0.584 .

2. The regression coefficient for needs is $\mathbf{0 . 4 1 1}$ which states that if the need increases, the intensity of use will increase by 0.411 and vice versa if the need decreases, the intensity of use will decrease.

3. The regression coefficient of convenience obtained is $\mathbf{0 . 3 3 6}$ which states that if the ease of use increases, the intensity of use will also increase by $\mathbf{0 . 3 3 6}$ and vice versa if the ease of use decreases, the intensity of use will also decrease.

The regression coefficient of confidence is $\mathbf{0 . 3 7 9}$ which states that if trust increases, the intensity of use will also increase by 0.379 and vice versa if trust decreases, the intensity of use will also decrease.

\subsection{Hypothesis testing}

\subsection{1. t test}

Table 4.4. Parisal test ( $\mathrm{t}$ test)

\begin{tabular}{|c|c|c|c|c|c|}
\hline \multirow{2}{*}{ Model } & \multicolumn{2}{|c|}{$\begin{array}{l}\text { Unstandardized } \\
\text { Coefficients }\end{array}$} & \multirow{2}{*}{ 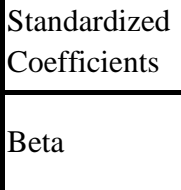 } & & \multirow{2}{*}{ Sig. } \\
\hline & B & $\begin{array}{l}\text { Std. } \\
\text { Error }\end{array}$ & & & \\
\hline (Constant) & -.584 & 1.040 & & -.561 & .576 \\
\hline Needs & .411 & .081 & .328 & 5.075 & .000 \\
\hline Convenience & .336 & .084 & .386 & 3.982 & .000 \\
\hline Trust & .379 & .130 & .259 & 2.906 & .004 \\
\hline
\end{tabular}

Source: Primary Data Processed, 2021

Based on table 4.4, the results of the t-test can be explained :

a) Effect of Need on Intensity of Use

Based on the results of multiple linear regression, it shows that the $t$ value is 5.075 and the significance value is 0.000 , then the need (X1) has an effect on the intensity of use, so that hypothesis 1 is accepted. 
b) Effect of Ease of Use on Intensity

Based on the results of multiple linear regression showing the t-count value of 3.982 and a significance value of 0.000 with a smaller significance value $(\mathrm{a}=0.05)$, then Ease $(\mathrm{X} 2)$ affects the Intensity of Use, so that hypothesis 2 is accepted.

c) The Effect of Trust on Intensity of Use

Based on the results of multiple linear regression showing the t-count value of 2.906 and a significance value of 0.004 with a smaller significance value $(\mathrm{a}=0.05)$, then Trust $(\mathrm{X} 3)$ has an effect on the Intensity of Use, so that hypothesis 3 is accepted.

\section{6. $\quad$ F Uji test}

The following are the results of the F test in the study:

Tabel 4.5. F . Test

\begin{tabular}{|l|r|r|r|r|r|}
\hline \multicolumn{1}{|c|}{ Model } & \multicolumn{1}{|c|}{$\begin{array}{c}\text { Sum of } \\
\text { Squares }\end{array}$} & \multicolumn{1}{c|}{ df } & $\begin{array}{c}\text { Mean Value } \\
\text { Square }\end{array}$ & \multicolumn{1}{c|}{ F } & \multicolumn{1}{c|}{ Sig. } \\
\hline 1 Regression & 383,996 & 3 & 127,999 & 86.066 & .000 \\
Residual & 154.671 & 104 & 1.487 & & \\
Total & 538,667 & 107 & & & \\
\hline
\end{tabular}

Source: Primary Data Processed, 2021

From table 4.5 above, it is shown that the calculated $\mathrm{F}$ is 86.066 with a significance level of 0.000 . Because the significance value of 0.000 is smaller than 0.05 , then $\mathrm{H} 4$ is accepted, meaning that the need, convenience and trust have an effect on the intensity of using mobile health applications in Pramita Lab Surabaya patients.

\subsection{Coefficient of Determination (R2)}

\begin{tabular}{|r|r|r|r|r|r|}
\multicolumn{7}{|c|}{ Tabel 4.6. Coefficient of Determination } \\
Model & $\mathrm{R}$ & R Square & $\begin{array}{l}\text { Adjusted } \\
\text { R Square }\end{array}$ & $\begin{array}{c}\text { Std. Error } \\
\text { of the Estimate }\end{array}$ & $\begin{array}{c}\text { Durbin- } \\
\text { Watson }\end{array}$ \\
\hline 1 & $.844^{\mathrm{a}}$ & .713 & .705 & 1.21951 & 1.861 \\
\hline
\end{tabular}

Based on table 4.26 above, it can be seen that the value of the coefficient of determination (R Square) is calculated by squaring the correlation coefficient $(\mathrm{R})$ where the value of $\mathrm{R}$ Square is 0.713 , meaning that $71.3 \%$ of the variation of the intensity of use can be explained by the three independent variables consisting of needs (X1), Ease (X2), Trust (X3). While the remaining $28.7 \%$ is explained by other reasons or influenced by other variables outside the independent variables studied.

\subsection{Classic assumption test}

\subsubsection{Normality test}

The following are the results of the normality test of the research model:.

Tabel 4.7. Normality Test with Kolmogorov-Smirnov

\begin{tabular}{|c|c|c|}
\hline \multicolumn{3}{|c|}{ One-Sample Kolmogorov-Smirnov Test } \\
\hline & & $\begin{array}{l}\text { Unstandardized } \\
\text { Residual }\end{array}$ \\
\hline \multicolumn{2}{|l|}{$\mathrm{N}$} & 108 \\
\hline \multirow[t]{2}{*}{ Normal Parameters ${ }^{\mathrm{a}}$} & Nilai Mean & .0000000 \\
\hline & Std. Deviation & 1.20229726 \\
\hline \multirow{3}{*}{$\begin{array}{l}\text { Most Extreme } \\
\text { Differences }\end{array}$} & Absolute & .080 \\
\hline & Positive & .063 \\
\hline & Negative & -.080 \\
\hline \multicolumn{2}{|c|}{ Kolmogorov-Smirnov Z } & .834 \\
\hline \multicolumn{2}{|c|}{ Asymp. Sig. (2-tailed) } & .490 \\
\hline
\end{tabular}

a. Test distribution is Normal. 
Based on Table 4.7, the data is normally distributed, using the Kolmogorov-Smirnov because it uses a sample $>30$. It can be seen in the table where the significance point is 0.490 . This indicates that the data has a normal distribution, as evidenced by the significance value above 0.05 .

\subsubsection{Multicollinearity Test}

The multicollinearity test was carried out with the aim of knowing the regression model found whether or not there was a correlation between the dependent or independent variables.

Table 4.8. Multicollinearity Test

\begin{tabular}{|l|l|l|}
\hline \multirow{2}{*}{ Model } & \multicolumn{2}{|c|}{$\begin{array}{c}\text { Collinearity } \\
\text { Statistics }\end{array}$} \\
\cline { 2 - 3 } & Tolerance & VIF \\
\hline 1 (Constant) & & \\
Kebutuhan & .662 & 1.512 \\
Kemudahan & .294 & 3.407 \\
Kepercayaan & .346 & 2.887 \\
\hline
\end{tabular}

Source: Primary Data Processed, 2021

In table 4.28, all independent variables namely need, convenience, trust and intensity of use have tolerance points above 0.10 and all VIF points $<10$. So it can be interpreted that VIF points are free from multicollinearity. For details, the tolerance value on the need $\rightarrow$ intensity of use $=1.512$; ease $\rightarrow$ intensity of use $=$ 3,407 ; confidence $\rightarrow$ intensity of use $=2.887$. So it can be concluded that there is no multicollinearity.

\subsubsection{Uji Heteroskedastisitas}

Heteroscedasticity was tested using the Spearman Rank correlation coefficient test, which correlates the absolute residuals of the regression results with all independent variables. The results of the heteroscedasticity test are shown in the following table.

Table 4.9. Heteroscedasticity Test

\begin{tabular}{|l} 
Correlations \\
\hline
\end{tabular}

**. Correlation is significant at the 0.01 level (2-tailed).

Source: Primary Data Processed, 2021

Table 4.9 produces significance points for all independent variables above 0.05 . These data indicate that there is no heteroscedasticity in the research conducted. 


\section{Conclusions and Practical Implication}

\subsection{Conclusions}

Based on the results of the analysis and discussion of the effect of Need, Ease, and Trust on the Intensity of Using Mobile Health Applications for Laboratory Examinations in Pramita Lab Surabaya Patients, it can be concluded:

1. The need has a positive and partially significant effect on the Intensity of Using Mobile Health Applications for Laboratory Examinations in Pramita Lab Surabaya Patients.

2. Ease has a positive and partially significant effect on the Intensity of Using Mobile Health Applications for Laboratory Examinations in Pramita Lab Surabaya Patients.

3. Trust has a positive and partially significant effect on the Intensity of Using Mobile Health Applications for Laboratory Examinations in Pramita Lab Surabaya Patients.

Need, Ease, and Trust together have a positive and significant effect on the Intensity of Using Mobile Health Applications for Laboratory Examinations in Pramita Lab Surabaya Patients.

\subsection{Practical Implication}

The managerial implications of the results of this study are presented in order to provide benefits for increasing the intensity of the use of mobile health applications to carry out laboratory examinations on Pramita Lab Surabaya patients. The following are managerial implications that can be concluded by researchers:

Table 5.1. Managerial Implications

\begin{tabular}{|l|l|}
\hline Before Research & After Research and Managerial Implications for Pramita Lab Surabaya Patients \\
\hline $\begin{array}{l}\text { Pramita Lab Surabaya's } \\
\text { patient needs are varied }\end{array}$ & $\begin{array}{l}\text { 1. In order to increase the patient's stimuli for achievement needs, the speed and agility of services can be } \\
\text { increased because this achievement need means that patients want services to be more efficient through } \\
\text { applications compared to offline. } \\
\text { 2. Improved features and services that understand patient needs to increase the intensity of use for Pramita } \\
\text { Lab Surabaya patients } \\
\text { 3. To measure the intensity of the use of mobile health applications on a regular basis for Pramita Lab } \\
\text { Surabaya patients }\end{array}$ \\
\hline $\begin{array}{l}\text { Ease of use of applications } \\
\text { that still need to be developed }\end{array}$ & $\begin{array}{l}\text { 1. The mobile health application program so that it is easy to learn by ordinary people is to provide: } \\
\text { a. Provide procedures for use at each location at Pramita Lab Surabaya } \\
\text { b. Prepare officers who can be contacted by patients to guide patients to make it easier to use the mobile } \\
\text { health application }\end{array}$ \\
\hline $\begin{array}{l}\text { Trust in using the application } \\
\text { needs improvement }\end{array}$ & $\begin{array}{l}\text { 1. In order to increase the benefits of the mobile health application, the services provided must be in } \\
\text { accordance with what is needed by the patient based on the application } \\
\text { 2. The features and services provided are in accordance with what is served on the application } \\
\text { 2. Provide a question and answer service for patients to trust mobile health applications more in order to } \\
\text { increase the intensity of use }\end{array}$ \\
\hline Varied Intensity of Use & $\begin{array}{l}\text { 1. Making the mobile health application an integrated system and directly connected with Pramita Lab } \\
\text { Surabaya for patient convenience so that its use will be further increased } \\
\text { 2. Pay attention to every feature with the services provided, in order to increase usage } \\
\text { 3. Increase the development of facilities and infrastructure to support the use of mobile health applications } \\
\text { 4. Provide opportunities for patients to ask questions either through the application or directly if there are } \\
\text { problems or obstacles. }\end{array}$ \\
\hline
\end{tabular}

\section{References}

Assauri, S. (2013). Marketing Management. Jakarta, Rajawali Pers.

Chiu, J. L., Bool, N. C., \& Chiu, C. L. (2017). Challenges and factors influencing initial trust and behavioral intention to use mobile banking services in the Philippines. Asia Pacific Journal of Innovation and Entrepreneurship, 11(2), 246-278. https://doi.org/10.1108/APJIE-08-2017-029

Dahne, J., \& Lejuez, C. W. (2015). Smartphone and mobile application utilization prior to and following treatment among individuals enrolled in residential substance use treatment. Journal of Substance Abuse Treatment, 58, 95-99. https://doi.org/10.1016/j.jsat.2015.06.017

Davis, F. D. (1989). Perceived usefulness, perceived ease of use, and user acceptance of information technology. 
MIS Quarterly, 13(3), 319-340. https://doi.org/10.2307/249008

Delone, W. H., \& McLean, E. R. (2003). The DeLone and McLean model of information systems success: A tenyear update. Journal of Management Information Systems, 19(4), 9-30. https://doi.org/10.1080/07421222.2003.11045748

Hamid, A. A., Razak, F. Z. A., Bakar, A. A., \& Abdullah, W. S. W. (2016). The effects of perceived usefulness and perceived ease of use on continuance intention to use e-government. Procedia Economics and Finance, 35, 644-649.

Hartono, J. (2009). Sistem informasi manajemen. Yogyakarta: Penerbit Andi.

Jogiyanto, H. M. (2007). Sistem informasi keperilakuan. Yogyakarta: Andi Offset.

Khaddafi, M., Aspan, H., Heikal, M., Wahyuddin, Falahuddin, \& ZatinHumaira. (2018). Effect of perception of facilities, intensity of conduct, and satisfaction of tax payers to submission of letter by E-Filing notice on tax service (pp. 583-587). https://doi.org/10.1108/978-1-78756-793-1-00001

Kotler, P., \& Armstrong, G. (2008). Prinsip-prinsip pemasaran (Edisi ke-1). Jakarta: Erlangga.

Kuncoro, M. (2013). Metode riset untuk bisnis dan ekonomi. Jakarta: Erlangga.

Maharani, A. D., \& Darmastuti, I. (2010). Analisis pengaruh kepercayaan dan kepuasan terhadap loyalitas nasabah tabungan Bank Mega Semarang. Universitas Diponegoro.

Mustaqim, I. (2017). Pengembangan media pembelajaran berbasis augmented reality. Jurnal Edukasi Elektro, 1(1), 36-48. https://doi.org/10.21831/jee.v1i1.13267

Noor, J. (2011). Metodologi penelitian: Skripsi, tesis, disertasi dan karya ilmiah. Kencana Prenada Media Group.

Özcan, Y. Z., \& Koçak, A. (2003). Research note: A need or a status symbol? European Journal of Communication, 18(2), 241-254. https://doi.org/10.1177/0267323103018002004

Purhantara, W. (2010). Metode penelitian kualitatif untuk bisnis. Graha ilmu.

Riduwan, M. B. A. (2010). Skala pengukuran variabel-variabel penelitian. In Alf. Bandung (Alf. Bandu). Bandung: Alfabeta.

Sanusi, A. (2012). Metode penelitian bisnis. Jakarta: PT. Salemba Empat.

Shaw, P., \& Tan, Y. (2015). Constructing digital childhoods in Taiwanese children's newspapers. New Media \& Society, 17(11), 1867-1885. https://doi.org/10.1177/1461444814535193

Sugiyono. (2010). Statistika untuk penelitian. Bandung: Alfabeta.

Sujarweni, V. W. (2015). Metodologi penelitian bisnis \& ekonomi (First). Pustaka Baru Press.

Wahyujatmiko, S., \& Yon Hadi, I. (2018). Manajemen pemasaran online makaroni Huhhah Yogyakarta. JBTI: Jurnal Bisnis Teori Dan Implementasi, 9(2). https://doi.org/10.18196/bti.92104

Xu, K., Ba, J., Kiros, R., Cho, K., Courville, A., Salakhudinov, R., Zemel, R., \& Bengio, Y. (2015). Show, attend and tell: Neural image caption generation with visual attention. International Conference on Machine Learning, 2048-2057.

Yuniar, G. S., \& Nurwidawati, D. (2013). Hubungan antara intensitas penggunaan situs jejaring sosial Facebook dengan pengungkapan diri (Self disclosure) pada siswa-siswi kelas VIII SMP Negeri 26. Character: Jurnal Penelitian Psikologi., 2(1), 1-7. 